\title{
2020: rok, kdy ambulantní dermatovenerologové vzali budoucnost do svých rukou. Konečně!
}

\author{
Ing. Jaroslav Duba \\ OAKS Consulting s.r.o., pověřený SAD k zastupování v jednáních o úhradách
}

Ačkoli uspořádání číslic 2-0-2-0 působí vyrovnaně a uhlazeně, samotný průběh letošního roku je plný turbulencí a neočekávaných zvratů. Středobodem, kolem kterého se vše točí, je samozřejmě COVID-19, který významnou měrou přispěl k rozpadu „zavedených pořádků“ v mnoha oblastech našeho života. Můžeme se tomu bránit, nebo přijmout fakt, že nastala nová éra bytí, která sice nese řadu nejistot, ale spolu s nimi i mnoho nových přiležitostí.

Stěžujeme si jen ze zvyku, nebo je ambulantní dermatovenerolog skutečně "ohroženým druhem"?

SAD, Sdružení ambulantních dermatovenerologů v ČR, z. s. (www.sadcr.com), si jako svưj hlavní cíl vytyčilo zajistit pro nestátní ambulantní zařizení odbornosti dermatovenerologie takové podmínky, které prínesou dlouhodobou ekonomickou stabilitu a perspektivu pro rozvoj oboru. Do roku 2020 jsme vstupovali prípraveni kjednáním o prosazení priorit SAD pro ambulantní dermatovenerology:

1. Nepodkročitelnou hodnotu bodu 1 Kč/bod

2. Promítnutí změn v bodových hodnotách výkonů do úhrad v daném roce

3. Valorizaci hodnoty práce $v$ bodových hodnotách výkonů

4. Zavedení dvou nových programů bonifikace úhrad za kvalitu

- Program bonifikace za kvalitu zaměřený na pacienty s psoriázou.

- Program bonifikace za kvalitu zaměřený na pacienty s atopickou dermatitidou

5. Změny ve zdravotních výkonech

- Změny ve způsobu vykazování a hrazení vyšetření kožních lézí

- Preventivní vyšetření kưže (s ohledem na prevenci kožních nádorů)

- Vyšetření s použitím dermatoskopu
- Zavedení nových výkonů:

- Ošetření pacienta s více diagnózami formou pričítacího kódu s časovou dotací 15 min (176 bodů), vykazovaného za každou další diagnózu

- Edukace pacienta s chronickými onemocněními kưže

- Navýšení času výkonů klinických vyšetření

- 44021 (komplexní vyšetření dermatovenerologem) z 30 min na 60 min

- 44022 (cílené vyšetření dermatovenerologem) z 20 min na 30 min

- 44023 (kontrolní vyšetření dermatovenerologem) z $10 \mathrm{~min}$ na $15 \mathrm{~min}$

Koncem ledna jsme oslovili všechny zdravotní pojištovny s žádostí o osobní schůzku k projednání výše uvedeného, ovšem bez reakce. O to s větším úsilím jsme se proto pripravovali na jednání v rámci Dohodovacího řizení. Cílem bylo prosadit v rámci Dohodovacího rízení priority 1,2 a 3 a otevř́it si dveře pro následná samostatná jednání SAD ohledně priorit 4 a 5.

První jednání segmentu ambulantních specialistů a zdravotních pojištoven se uskutečnilo 16. 4. 2020 a od první chvíle hrála koalice SAD se Sdružením ambulantních internistů v ČR (SAI) a Sdružením poskytovatelů ambulantní péče $v$ gastroenterologii (SPGE) klíčovou roli. Valorizace hodnoty práce je jednoznačně zá- sluhou prezidenta ČLK, MUDr. Kubka. Naše koalice jeho úsilí jako jediná ze všech sdružení ambulantních poskytovatelů veřejně a na pưdě všech jednání podporovala a spolu s prosazením priorit SAD, nepodkročitelné korunové hodnoty bodu 1 Kč a promítnutím změn v bodových hodnotách výkonů do úhrad, se tak můžete těšit na 10\% navýšení od ledna 2021 a dalších 10 \% pak od ledna 2022. Po náročných diskuzích se koalici SAD-SAI-SPGE podařilo ostatní přesvědčit a všechny naše priority prosadit.

Dohoda pro rok 2021, kterou považujeme za historicky nejlepší výsledek vyjednaný pro ambulantní specialisty, pak vyšla 30. 10. 2020 ve Sbírce zákonů, v príloze č. 3 vyhlášky č. 428/2020 Sb., pod názvem „Vyhláška o stanovení hodnot bodu, výše úhrad hrazených služeb a regulačních omezení pro rok 2021“, jejíž stručný přehled hlavních bodů naleznete níže:

- Promítnutí změn v bodových hodnotách výkonů do úhrad $v$ daném roce

- Nepodkročitelná hodnota bodu 1 Kč/bod

- Základní korunová hodnota bodu 1,05 Kč s možnou bonifikací až na 1,15 Kč

- Základní koeficient navýšení PURO 5 \% s možnou bonifikací až na $17 \%$

- Poskytovatel, který má více odborností a splní v součtu podmínku pro bonifikaci za dodržení požadovaného rozsahu pracovní doby, má na bonifikaci nárok 
Výkonová úhrada u poskytovatele, který v roce 2021 ošetří 100 a méně pojištěnců od dané pojištovny

- U nových poskytovatelů se PURO nastaví podle srovnatelných poskytovatelů se zohledněním rozsahu a struktury poskytované péče, tj. ne pouhým průměrem v odbornosti

- Navýšení limitu regulací (preskripce i vyžádaná péče) na $108 \%$

Celkem proběhlo v rámci Dohodovacího rízení devět náročných jednání v on-line režimu, ale těší nás, že SAD v duchu svých cílů prìspělo výraznou měrou ke zvýšení ekonomické stability a perspektivy v odbornosti dermatovenerologie.

Bezprostředně po skončení Dohodovacího řizení oslovil výbor SAD znovu všechny zdravotní pojištovny s žádostí o schůzku k projednání bonifikačních programů za kvalitu a změn ve zdravotních výkonech a 25. 8. 2020 proběhlo první jednání SAD se zástupci svazových zdravotních pojištoven. Velice nás těší, že všech šest pojištoven vnímá neutěšenou situaci ambulantních dermatovenerologů a tři z nich, konkrétně OZP (207), ČPZP (205) a ZP MV (211) projevily vážný zájem o zapojení se do programů kvality SAD, Q-LUPÉNKA a Q-EKZÉM. Našim cílem je, aby tyto programy byly zohledněny v rámci úhradových dodatků platných pro rok 2021.

Zatímco v rámci Dohodovacího rízení musí dojít ke konsenzu zástupců jednotlivých spolků ambulantních poskytovatelů (v letošním roce jich bylo 29) a 7 zdravotních pojištoven a dojednaný výsledek platí pro všechny ambulantní specialisty stejně, výstupy z jednání, která vede SAD výhradně v zájmu ambulantních dermatovenerologů, prìnáší benefity jen a pouze pro ambulantní dermatovenerology. Poskytovatelé, které SAD zastupuje a kteři se pak do bonifikačních programů aktivně zapojí, získají významné navýšení úhrad nad rámec úhrad daných úhradovou vyhláškou. Jinými slovy řečeno, nejste-li členem SAD, nemá SAD mandát za vás jednat. Pokud dáte plnou moc spolku, jako je SAS nebo ČLK, budou Vás jejich reprezentanti zastupovat jen a pouze v Dohodovacím řizení. Pokud ale chcete víc (valorizace výkonů, zavedení nových výkonů, nadstandardní úhradu za vámi garantovaný standard kvality péče), nikdo jiný, než SAD to pro vás nevyjedná.

O veškerém dění, včetně průběhu jednání s plátci, informuje SAD pravidelně své členy. Pokud chcete benefitovat z toho, co pro ambulantní dermatovenerology SAD dělá, vyplňte a pošlete přihlášku, kterou naleznete na našich stránkách www.sadcr.com.

\section{Programy kvality Q-LUPÉNKA a Q-EKZÉM - cesta k dlouhodobé stabilitě v oboru}

Programy bonifikace za kvalitu považuje SAD za stěžejní pro zajištění dlouhodobé ekonomické stability a perspektivy ambulantních dermatovenerologů. Výbor SAD se proto rozhodl zveřejnit jejich obsah tak, jak byly představeny zdravotním pojištovnám. Podrobný popis naleznete na našem webu www.sadcr.com.

\section{SAD bonifikační program \\ kvality Q-LUPÉNKA}

Cílem programu je: Zajištění komplexní hrazené péče pro pacienty s lupénkou dle doporučených postupů a poznatků vědy, která bude pro zdravotní systém predikovatelná z pohledu prínosů, nákladů a dlouhodobé finanční udržitelnosti.

Po spuštění projektu Q-LUPÉNKA budou poskytovatelé v odbornosti 404 a/nebo 405 u pacientů s lupénkou (MKN diagnóza L40) postupovat dle aktuálních guidelines, včetně hodnocení PASI u každého pacienta, a zaznamenávat požadovaná data pro průběžné vyhodnocování úspěšnosti programu. Za to získají od zdravotních pojištoven zapojených do projektu finanční bonifikaci, prípadně další benefity.

\section{SAD bonifikační program kvality Q-EKZÉM}

Cílem programu je: Zajištění komplexní hrazené péče pro pacienty s ekzémem dle doporučených postupů a poznatků vědy, která bude pro zdravotní systém predikovatelná z pohledu př́nosů, nákladů a dlouhodobé finanční udržitelnosti.

Po spuštění projektu Q-EKZÉM budou poskytovatelé v odbornosti 404 a/nebo 405 u pacientů s atopickým ekzémem (MKN diagnóza L20) postupovat dle aktuálních guidelines, včetně hodnocení SCORAD u každého pacienta, a zaznamenávat požadovaná data pro průběžné vyhodnocování úspěšnosti programu. Za to získají od zdravotních pojištoven zapojených do projektu finanční bonifikaci, případně další benefity.

Oba programy SAD se zcela zásadně liší od všech ostatních dosavadních programů i registrů v tom, že lékaři nikam nepřepisují žádné informace, které již existují v elektronické podobě.

Obr. 1. Činnosti ambulantního dermatovenerologa v rámci SAD programů kvality

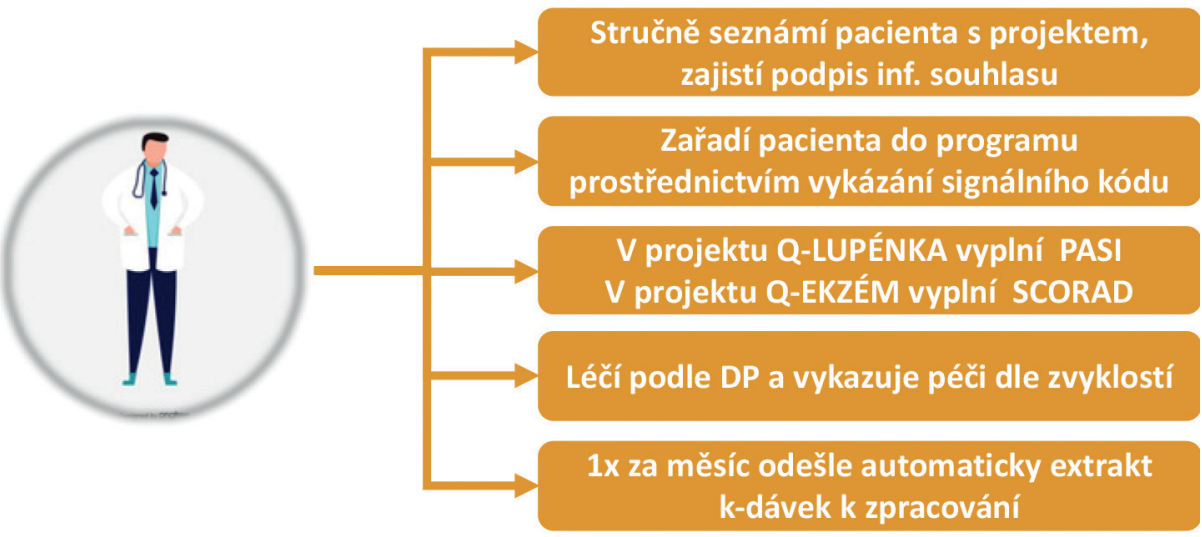

Obr. 2. SAD návrh bonifikačního mixu pro lékaře zapojené do programů kvality (záměr)

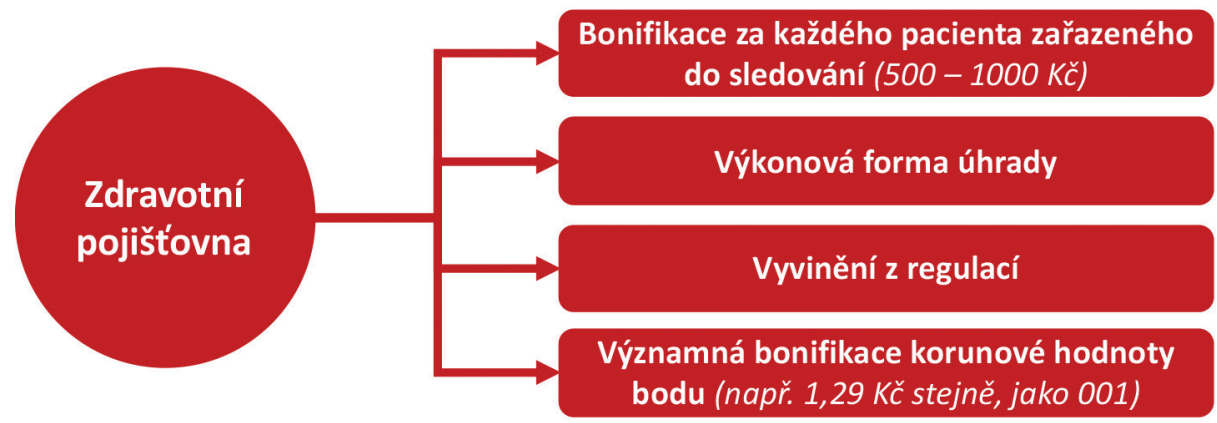




\section{SDRUŽENÍ AMBULANTNÍCH DERMATOLOGŮ INFORMUJE}

2020: ROK, KDY AMBULANTNÍ DERMATOVENEROLOGOVÉ VZALI BUDOUCNOST DO SVÝCH RUKOU. KONEČNĚ!

Jedinou manuální činností, nad rámec běžných činností, bude hodnocení PASI, resp. SCORAD, nicméně i to je částečně automatizované díky aplikaci, která byla za tím účelem speciálně vytvořena. Lékaři se tak mohou soustředit na péči o pacienta a netráví čas zbytečnou administrativou. Sebevědomě proto naše programy nazýváme „e-health projekty", které jsou svého druhu prvními v ČR. Rozsah činností lékaře, který se do SAD programů kvality zapojí, je uveden na obrázku 1.

Konečná podoba bonifikačního mixu je předmětem probíhajících jednání se zdravotními pojištovnami s tím, že jako podklad slouží návrh SAD (obr. 2).
Za poslední rok se SAD konečně podařilo dát věci do pohybu správným směrem, a to i přes neprízeň doby "kovidové", a věríme, že tyto dva projekty kvality v roce 2021 spustíme a budeme moci pokračovat i v dalších. Pokud máte zájem se do programů kvality SAD zapojit, neváhejte nás kontaktovat na info@sadcr.com. 